\title{
Efficacy of Entrophospora sp. (VA Mycorrhiza) on Salt Tolerance and Vegetative Growth of Chrysanthemum var. Marigold [Dendranthema grandiflora Tzvelev.]
}

\author{
Irappa Kumbar*, Chaya P. Patil, Mukund Shiragur, Balaji S. Kulkarni and A.M. Shirol \\ Department of Floriculture and Landscape Architecture, Kittur Rani Channamma College of \\ Horticulture, Arabhavi University of Horticultural Sciences Bagalkot, Karnataka, India \\ *Corresponding author
}

\begin{tabular}{|c|c|}
\hline \multicolumn{2}{|r|}{ A B S T R A C T } \\
\hline & \multirow{6}{*}{$\begin{array}{l}\text { The present investigation was aimed at determining the effects of vesicular arbuscular } \\
\text { mycorrhiza (VAM) on vegetative growth of chrysanthemum var. Marigold plants grown } \\
\text { under salinity condition. Entrophospora sp. (VAM) inoculated plants of forty-five days old } \\
\text { seedlings (DAS) were transplanted into pots (one seedling per pot) until the flowering. } \\
\text { After ( } 75 \text { days) transplanting, seedlings of chrysanthemum var. Marigold were treated with } \\
1.15 \text { (control) } 2,4 \text { and } 6 \mathrm{dS} / \mathrm{m} \text { saline irrigation water and observations showed that whole } \\
\text { plant height, number of leaves and branches, N-S and E-W plant spread, leaf area, number } \\
\text { of primary and secondary roots, shoot and root length, fresh and dry weight decreased with } \\
\text { increasing dose of salinity. Among these treatments, VA mycorrhiza treated plants } \\
\text { enhanced vegetative parameters when compared to control plants. VA mycorrhiza } \\
\text { promotes salinity tolerance by employing various mechanisms, such as enhancing nutrient } \\
\text { acquisition, producing plant growth hormones, improving rhizophoric and soil condition, } \\
\text { altering the physiological and biochemical properties of the host. The overall results } \\
\text { suggest that mycorrhizal colonization improves host plant mineral concentration and } \\
\text { vegetative growth and development of chrysanthemum var. Marigold plants under salinity } \\
\text { stress. }\end{array}$} \\
\hline & \\
\hline $\begin{array}{l}\text { Salt tolerance, } \\
\text { Vegetative growth, } \\
\text { Marigold. }\end{array}$ & \\
\hline Article Info & \\
\hline $\begin{array}{l}\text { Accepted: } \\
\text { 29 September } 2017 \\
\text { Available Online: } \\
10 \text { October } 2017\end{array}$ & \\
\hline & \\
\hline
\end{tabular}

\section{Introduction}

Chrysanthemum (Dendranthema grandiflora Tzvelev.) is one of the most interesting and oldest flower crops. Chrysanthemum belongs to the family Asteraceae with diploid chromosome number $(2 n=36)$. It is a leading commercial crop grown for cut, loose flowers and pot plant. (Bhattacharjee, 2006). Chrysanthemum includes more than 200 species of annuals and herbaceous perennials and is native to northern hemisphere, chiefly Europe and Asia. Chrysanthemums are widely spread in temperate, tropical and subtropical regions of the globe. All these make the Chrysanthemum flower suitable for various purposes like bedding plant, vase decorations, garland making and for garden display.

Salinity is one of the major problems which farmers are facing and needs an immediate attention to solve this problem. FAO estimated that globally the total salt affected area 12,781 million ha in which saline soils was 397 million ha and that of sodic soils 434 million ha (Arora et al., 2017). In 
India total salt affected area is $6.74 \mathrm{~m}$ ha affected with salinity problems Anon. (2015).

Salinity is an abiotic stress that results in negative effects on plant survival and considered as the most important abiotic factor limiting plant growth and yield by inducing severe physiological dysfunctions and causing widespread direct and indirect harmful effects. High salinity causes both hyper osmotic and ionic stress causing plant death (Yeo, 1998). Reduction in assimilates partitioning to roots and imbalance in overall concentrations of the ions due to ion toxic effect on physiological processes (Kokasal, et al., 2016) Presence of excess salts, particularly sodium, chlorine and free calcium is detrimental for the growth, physiology and nutrient uptake of Chrysanthemums (Lee et al., 2008).

One of the natural and technological ways which has been among the most studied subjects for the last decades to reduce the salinity damages in horticultural and agricultural crops is the inoculation with Vesicular Arbuscular Mycorrhiza (VAM) fungus. Plants inoculated with VAM maintain relatively higher water content compared to uninoculated plants (Colla et al., 2008; Sheng et al., 2008). This is facilitated by the improved hydraulic conductivity of the root at low water potential (Kapoor et al., 2008). The improved root conductance is associated with a longer root and an altered root system morphology induced by VAM (Dehne, 1982, Kothari et al., 1990). Improves chlorophyll and carotenoid content (Basak et al., 2011) thus maintains osmotic adjustment. Application of AM fungi increases antioxidant enzymatic activity and auxine concentration in plants. Application of VAM Fungi helps in accumulations of phosphorous, potassium, calcium, magnesium and potassium to nitrogen ratio and all the above mechanisms help to mitigate the negative effect of salinity (Abeer et al., 2015). Keeping in view of the above points, the present study the vegetative growth and salinity tolerance of Chrysanthemum var. marigold when inoculated with VAM (Entrophospora sp.) was conducted.

\section{Materials and Methods}

The experiment was conducted using two factorial complete randomized design with VA Mycorrhiza (Entrophospora sp.) and non mycorrhiza combined with four concentration of $\mathrm{NaCl}$ (1.15 (control), 2, 4 and $6 \mathrm{dS} / \mathrm{m}$ ). These eight treatments were replicated 3 time (each row contain 8 pot plants) to give a total of 192 pots. The data in all the experiments was statistically analysed by the method of analysis of variance as per Panse and Sukhatme (1989). Plants were grown under shade house condition. At the Kittur Rani Channamma College of Horticulture, Arabhavi. University of Horticultural Sciences, Bagalkot, Karnataka, India.

Entrophodpora sp. (VA Mycorrhiza) inoculum was mixed with coco peat in the ratio of 1: 3 and $80 \mathrm{~g}$ of this mixture was used to fill $100 \mathrm{~g}$ capacity polybags. VAM mixture filled and a hole was made. Chrysanthemum var. Marigold cuttings were placed in the hole such that maximum root surface was in contact with the mixture. Later some amount of VAM mixture was covered and polybags were irrigated with water. They were allowed to establishing for one and half months later, they were transplanted to bigger pots with capacity of $10 \mathrm{~kg}$ soil. Salt treatments were imposed two and half month after transplanting.

Chrysanthemum var. Marigold plants, moderately salt tolerant crop. Chrysanthemum multiplication was done by using shoot tip cuttings from mother plants. Cuttings were prepared as basal $10-12 \mathrm{~cm}$ long cuttings, 
planted in coco peat with and without Entrophospora sp. inoculums. One and half month old uniform rooted cuttings were transplanted to pots. After 75 days of transplanting, each treatment of mycorrhizal and non mycorrhizal plants was irrigated with an equal $(1000 \mathrm{ml})$ volume of the corresponding $\mathrm{NaCl}$ at weekly intervals. Leaching was prevented by keeping the soil below the field capacity at all times. Alternatively Groundnut cake and Neem cake extracts $(100 \mathrm{ml})$ were used as additional supply of nutrients for plants growth at fortnight interval. Plants were harvested 6 month after transplanting.

Morphological data were recorded on the marked plants from which plant height (soil line to plant tip), number of leaves per plant, number of branches per plant (including primary and secondery branchess), plant spread (North to South and East to West) measurements were recorded monthly intervals. Leaf area, shoot length (after detaching of root part), root length (after detachment of shoot part), number of roots (primary and secondary roots) were recorded during harvesting of crop.

\section{Results and Discussion}

Mycorrhiza inoculated plants growth and biomass was more than the uninoculated plants before imposition salt (at 75 days). $\mathrm{NaCl}$ stress significantly reduced plant growth and biomass of both mycorrhizal and nonmycorrhizal Chrysanthemum var. Marigold plants compared with control treatment and the rate of reduction increased with increasing $\mathrm{NaCl}$ concentration in the soil. However, the reduction in most growth criteria was more distinct in non-mycorrhizal Chrysanthemum var. Marigold plants (Table $1 \mathrm{~A}$ and 1B). In general, VAM plants had significantly higher Plant height, No. of leaves, No. of branches, Leaf area $\left(\mathrm{cm}^{2}\right)$,
Number of primary roots, Number of secondary roots, shoot and root length than those of non-mycorrhizal plants at all salt levels. Interactions between salinity and mycorrhizal colonization were significant for all character, except root length.

Salinity is one of the major constraints limiting crop productivity worldwide (Heyward and Bernstein, 1990). Soil salinity decreases crop yield by increasing the osmotic stress, nutrient deficiency and affecting various physiological and biochemical mechanism associated with plant growth and development (Colla et al., 2008; Sheng et al., 2008; Kokasal, et al., 2016,; Abeer et al., 2015). It appears from present study that salinity stress significantly reduced growth responses of mycorrhizal and non mycorrhizal Chrysanthemum var. Marigold compared with the control treatment plants. However, VAM inoculation improves growth and biomass of Chrysanthemum var. Marigold grown in either salt stressed or control soils compared to non mycorrhizal plants. The rate of growth of mycorrhizal colonization also decreased with increased salinity level these results are In accordance with the earlier reports on the plant species (Belew et al., 2010). Plants in saline conditions has been related partially to mycorrhizal mediated enhancement of host plant P nutrition (Belew et al., 2010; Asrar et al., 2014) interestingly mycorrhizal Chrysanthemum var. Marigold plants absorbed more available nutrients from (NPK) soil than non mycorrhizal plants in a salt stress treatment. It is evident from the study that plant tolerance to salt stress was improved greatly by Entrophospora sp. (VA Mycorrhizal colonization). We suggested that better growth and biomass in inoculated Chrysanthemum var. Marigold plants is an indication of enhanced salt tolerance to salt stress. 
Table.1A Effect of Entrophospora sp. and salinity on growth parameters of Chrysanthemum var. Marigold

\begin{tabular}{|c|c|c|c|c|c|c|}
\hline \multirow{3}{*}{ Treatments } & \multicolumn{2}{|c|}{ Plant height } & \multicolumn{2}{|c|}{ Number of leaves } & \multicolumn{2}{|c|}{ Number of branches } \\
\hline & \multicolumn{6}{|c|}{ Days after planting } \\
\hline & 75 & 210 & 75 & 210 & 75 & 210 \\
\hline \multicolumn{7}{|l|}{ VAM effect } \\
\hline $\mathbf{M}_{\mathbf{0}}$ & 18.05 & 48.05 & 21.78 & 154.48 & 2.29 & 9.67 \\
\hline $\mathbf{M}_{1}$ & 19.85 & 51.80 & 29.92 & 172.85 & 3.58 & 12.25 \\
\hline S. Em \pm & 0.32 & 0.44 & 1.05 & 1.07 & 0.16 & 0.14 \\
\hline CD at $5 \%$ & 0.95 & 1.31 & 3.14 & 3.21 & 0.47 & 0.42 \\
\hline \multicolumn{7}{|l|}{ Salt effect } \\
\hline $\mathbf{S}_{\mathbf{0}}$ & 19.65 & 54.55 & 24.60 & 176.93 & 2.82 & 12.03 \\
\hline $\mathbf{S}_{1}$ & 19.22 & 53.73 & 27.17 & 183.57 & 3.20 & 12.33 \\
\hline $\mathbf{S}_{2}$ & 18.70 & 50.10 & 26.37 & 161.23 & 2.89 & 10.90 \\
\hline $\mathbf{S}_{3}$ & 18.23 & 41.32 & 25.27 & 132.93 & 2.83 & 8.57 \\
\hline S. Em \pm & 0.45 & 0.62 & 1.48 & 1.51 & 0.22 & 0.20 \\
\hline CD at $5 \%$ & NS & 1.85 & NS & 4.54 & NS & 0.59 \\
\hline \multicolumn{7}{|c|}{ Interaction effect } \\
\hline$\overline{\mathbf{M}_{0} \mathbf{S}_{0}}$ & 18.64 & 53.13 & 21.27 & 171.80 & 2.11 & 10.80 \\
\hline $\mathbf{M}_{0} S_{1}$ & 18.77 & 49.90 & 23.80 & 179.47 & 2.47 & 11.27 \\
\hline $\mathbf{M}_{0} \mathbf{S}_{2}$ & 17.79 & 49.30 & 21.53 & 158.47 & 2.25 & 10.13 \\
\hline $\mathbf{M}_{0} \mathbf{S}_{3}$ & 17.00 & 39.87 & 20.53 & 108.20 & 2.33 & 6.47 \\
\hline $\mathbf{M}_{1} \mathbf{S}_{\mathbf{0}}$ & 20.67 & 55.97 & 27.93 & 182.07 & 3.53 & 13.27 \\
\hline $\mathbf{M}_{1} \mathbf{S}_{1}$ & 19.67 & 57.57 & 30.53 & 187.67 & 3.93 & 13.40 \\
\hline $\mathbf{M}_{1} \mathbf{S}_{2}$ & 19.61 & 50.90 & 31.20 & 164.00 & 3.53 & 11.67 \\
\hline $\mathbf{M}_{1} \mathbf{S}_{3}$ & 19.45 & 42.77 & 30.00 & 157.67 & 3.33 & 10.67 \\
\hline S. Em \pm & 0.63 & 0.87 & 2.09 & 2.14 & 0.31 & 0.28 \\
\hline CD at $5 \%$ & NS & 2.62 & NS & 6.41 & $\mathrm{NS}$ & 0.84 \\
\hline
\end{tabular}

NS: Non significant

$\mathrm{M}_{0}$ - Without Entrophospora sp. (VA Mycorrhiza) $\mathrm{M}_{1}$ - With Entrophospora sp. (VA Mycorrhiza) $\mathrm{S}_{0}$ - Normal water $(1.15 \mathrm{dS} / \mathrm{m}) \mathrm{S}_{1}-2 \mathrm{dS} / \mathrm{m} \mathrm{S}_{2}-4 \mathrm{dS} / \mathrm{m} \mathrm{S}_{3}-6 \mathrm{dS} / \mathrm{m}$ 
Table.1B Effect of Entrophospora sp. and salinity on growth parameters of Chrysanthemum var. Marigold

\begin{tabular}{|c|c|c|c|c|c|}
\hline Treatments & $\begin{array}{c}\text { Leaf area } \\
\left(\mathrm{cm}^{2}\right)\end{array}$ & $\begin{array}{c}\text { Shoot } \\
\text { Length }(\mathbf{c m})\end{array}$ & $\begin{array}{c}\text { Root } \\
\text { Length } \\
\text { (cm) }\end{array}$ & $\begin{array}{c}\text { Number of } \\
\text { primary } \\
\text { roots }\end{array}$ & $\begin{array}{c}\text { Number of } \\
\text { secondary } \\
\text { roots }\end{array}$ \\
\hline \multicolumn{6}{|l|}{ VAM effect } \\
\hline $\mathbf{M}_{0}$ & 1948.92 & 52.36 & 30.88 & 57.58 & 190.50 \\
\hline $\mathbf{M}_{1}$ & 2635.18 & 56.96 & 34.88 & 80.33 & 265.50 \\
\hline S. Em \pm & 25.28 & 0.73 & 0.68 & 2.01 & 5.49 \\
\hline CD at $5 \%$ & 75.80 & 2.19 & 2.04 & 6.04 & 16.45 \\
\hline \multicolumn{6}{|l|}{ Salt levels } \\
\hline $\mathbf{S}_{\mathbf{0}}$ & 2757.37 & 61.33 & 38.25 & 89.50 & 283.50 \\
\hline $\mathbf{S}_{1}$ & 2467.49 & 58.75 & 35.33 & 75.33 & 260.83 \\
\hline $\mathbf{S}_{2}$ & 2152.50 & 52.17 & 32.17 & 64.50 & 212.17 \\
\hline $\mathbf{S}_{\mathbf{3}}$ & 1790.83 & 46.38 & 25.75 & 46.50 & 155.50 \\
\hline S. Em \pm & 35.76 & 1.03 & 0.96 & 2.85 & 7.76 \\
\hline CD at $5 \%$ & 107.20 & 3.10 & 2.89 & 8.54 & 23.26 \\
\hline \multicolumn{6}{|c|}{ Interaction effect } \\
\hline $\mathbf{M}_{0} \mathbf{S}_{0}$ & 2541.04 & 56.50 & 33.83 & 71.67 & 228.67 \\
\hline $\mathbf{M}_{0} \mathbf{S}_{1}$ & 2057.66 & 56.00 & 33.50 & 64.67 & 220.67 \\
\hline $\mathbf{M}_{0} \mathbf{S}_{2}$ & 1747.33 & 51.67 & 31.50 & 59.33 & 191.67 \\
\hline $\mathbf{M}_{0} \mathbf{S}_{3}$ & 1449.67 & 45.27 & 24.67 & 34.67 & 121.00 \\
\hline $\mathbf{M}_{1} \mathbf{S}_{0}$ & 2973.70 & 66.17 & 42.67 & 107.33 & 338.33 \\
\hline $\mathbf{M}_{1} \mathbf{S}_{1}$ & 2877.33 & 61.50 & 37.17 & 86.00 & 301.00 \\
\hline $\mathbf{M}_{1} \mathbf{S}_{2}$ & 2557.67 & 52.67 & 32.83 & 69.67 & 232.67 \\
\hline $\mathbf{M}_{1} \mathbf{S}_{3}$ & 2132.00 & 47.50 & 26.83 & 58.33 & 190.00 \\
\hline S. Em士 & 50.57 & 1.46 & 1.36 & 4.03 & 10.97 \\
\hline CD at $5 \%$ & 151.61 & 4.38 & ns & 12.07 & 32.90 \\
\hline
\end{tabular}

Ns: Non significant

$\mathrm{M}_{0}$ - Without Entrophospora sp. (VA Mycorrhiza) $\mathrm{M}_{1}$ - With Entrophospora sp. (VA Mycorrhiza) $\mathrm{S}_{0}$ - Normal water (1.15 dS/m) $\mathrm{S}_{1}-2 \mathrm{dS} / \mathrm{m} \mathrm{S}_{2}-4 \mathrm{dS} / \mathrm{m} \mathrm{S}_{3}-6 \mathrm{dS} / \mathrm{m}$

Use of Entrophospora sp. VA mycorrhizal fungus enhances growth and biomass of Chrysanthemum var. Marigold. Through enhancing nutritional status, water uptake and toxic ions exclusion like $\mathrm{Na}^{+}$and $\mathrm{Cl}^{-}$. All vegetative growth of plants was found to be significant at control salinity and $2 \mathrm{dS} / \mathrm{m}$ salinity level but reduction in plants growth were observed at $4 \mathrm{dS} / \mathrm{m}$ salinity level so Chrysanthemum var. Marigold is a moderate salt tolerant crop.

\section{References}

Abeer, H., Ef, A. A., Alqarawi, A. A., Mona, S. A., Alenazi, M. M., Egamberdieva, D. and Ahmad, P., 2015. Arbuscular mycorrhizal fungi mitigates $\mathrm{NaCl}$ induced adverse effects on Solanum lycopersicum L. Pak. J. Bot., 47(1): 327-340.

Anonymous, 2015. Annual Report of Central Soil Salinity Research Institute (CSSRI), Karnal.

Arora, S., Singh, A. K. and Shing, Y. P. (eds.), 2017. Bioremediation of salt 
affected soils: An Indian. Perspective. Springer, pp. 313.

Asrar, A. W. A., Fattah, G. M. A., Elhindi, K. M. and Salam, E. M. A., 2014. The impact of arbuscular mychorrhizal fungi in improving growth, flower yield and tolerance of kalanchoe (Kalanchoe blossfeldiana Poelin) plants grown in NaCl-stress conditions. J. of Food, Agriculture \& Environment, 12(1):105112.

Basak, H., Demir, K., Kasim, R. and Okay, F.Y., 2011. The effect of endomycorrhiza (VAM) treatment on growth of tomato seedling grown under saline conditions. African J. Agric. Res., 6(11): 2532-2538.

Belew, D., Astatki, T., Mokashi, M. N., Getachew, Y. and Patil, C. P., 2010. Effects of salinity and mycorrhizal inoculation (Glomus fasciculatum) on growth responses of grape rootstocks (Vitis spp.). S. Afr. J. Eno L Vitic., 2(31): 82-88.

Bhattacharjee, S. K., 2006. Advances in ornamental horticulture, Aavishkar Publishers, distributors, 2: 80-108.

Colla, G., Rouphael, Y., Cardarelli, M., Tullio, M., Rivera, C. M. and Rea, E., 2008. Alleviation of salt stress by arbuscular mycorrhiza in zucchini plants grown at low and high phosphorous concentration. Biol. Fertil. Soils, 44: 501509.

Dehne, H. W., 1982. Interaction between vesicular- arbuscular mycorrhizal fungi and plant pathogens. Phytopathology, 72: 1115-1119.
Glenn, E. P., Brown, J. J., Blumwald, E., 1999. Salt tolerance and crop potential of halophytes. Crit Rev Plant Sci., 18: 227255.

Heyward, H. E., and Bernstein, L., 1990. Plant-growth relationships on saltaffected soils. Scientia Horticulturae, 128: 128-258.

Kapoor, R., Sharma, D., Bhatnagar, A. K., 2008. Arbuscular mycorrhizae in micropropagation systems and their potential applications. Sci Hort., 116: 227-239.

Koksal, N., Torun, A. A., Kulahlioglu, I., Ertargin, E. and Karalar, E., 2016. Ion uptake of marigold under saline growth conditions, Springer Plus, 5: 139.

Kothari, S. K., Marschner, H. and George, E., 1990. Effect of VA mycorrhizal fungi and rhizosphere microorganism on root and shoot morphology, growth and water relations of maize. New Phytologist, 116: 303-311.

Lee, M. K., and Iersel, M. W. V., 2008. Sodium chloride effects on growth, morphology and physiology of Chrysanthemums [Chrysanthemum $x$ morifolium]. Hort. Sci., 43: 1888-1891.

Sheng, M., Tang, M., Chan, H., Yang, B., Zhang, F., Huang, Y., 2008. Influence of arbuscular mycorrhizae on photosynthesis and water status of maize plants under salt stress. Mycorrhiza, 18: 287-296.

Yeo, A., 1998. Molecular biology of salt tolerance in the context of whole-plant physiology, J. Exp. Bot., 49(323): 915929.

\section{How to cite this article:}

Irappa Kumbar, Chaya P. Patil, Mukund Shiragur, Balaji S. Kulkarni and Shirol, A.M. 2017. Efficacy of Entrophospora sp. (VA Mycorrhiza) on Salt Tolerance and Vegetative Growth of Chrysanthemum var. Marigold [Dendranthema grandiflora Tzvelev.]. Int.J.Curr.Microbiol.App.Sci. 6(10): 4763-4768. doi: https://doi.org/10.20546/ijcmas.2017.610.442 